\title{
ДОСВІД ОРГАНІЗАЦІЇ ДИСТАНЦЙНОГО НАВЧАННЯ В КИТАЇ
}

У статті представлено досвід Китаю, визнаного одним із лідерів у сфері впровадження дистанційної освіти. Завданнями дослідження е висвітлення історії розвитку дистанційної освіти в Китаї, визначення особливостей та шляххі їі ефективного впровадження. Методологічну основу становлять концептуальні положення порівняльної педагогіки, питання економічного розвитку в КНР, історичні аспекти розвитку китайської системи освіти, проблеми професійної підготовки вчителів у КНР, історія дистанційної освіти в Китаї. Наведено підходи, які окреслюють аспекти дистанційної освіти: 1) наявність географічної дистанції між учнем та вчителем (студентом або викладачем) у процесі навчання; 2) присутність нового типу освітньої комунікацій, який обумовлений поділом процесів викладання та навчання в часі та просторі; 3) вивчення дистанційної освіти як нової технологічної форми навчання, що виникла в інформаційному суспільстві. Визначено три підходи до феномена «дистанційне навчання»: теорія індустріалізациї, концепт відстані та характер освітньої комунікації. Застосовано такі методи дослідження як узагальнення та порівняння, які дозволяють вивчати зв'язки між різними підходами; метод класифікацій понять; метод критичного мислення та метод прогностичного дослідження.

Акцентовано увагу на використанні масових відкритих онлайн-курсів (МООС), які користуються попитом у КНР. Наведено переваги МООС: відкритість, масовість та адаптивність. Окреслено труднощі щодо використання МООС: відсутність особистісної взаємодії між викладачами та студентами; обмеженість обсягу та різноманітності навчальних ресурсів та справедливість системи оцінювання. Проаналізовано освітні платформи які надають можливість організації MOOC: «XиetangX» ma» iCourse». Новизна дослідження полягае у визначенні ефективних та перевірених засобів організації дистанційного навчання КНР, які можуть бути оперативно апробовані в украйнській системі освіти.

Ключові слова: цุифровізація освіти, COVID-19, дистанійне навчання, Китай, МООС, онлайн-занятты, Xuetang X, iCourse International.

Постановка проблеми. Стратегічним зовнішньополітичним завданням будь-якої держави є зміцнення іï позицій та авторитету на міжнародній арені. Інструменти, які використовуються для реалізації визначеної мети, змінюються від однієї епохи до іншої. Сьогодні в умовах глобалізації та формування нової подіцентричної системи міжнародних відносин поряд із військово-політичним потенціалом та економічними ресурсами на передній план постають культурні чинники, де головну роль відіграє освіта. Це пов'язано 3 усвідомлення того, що традиційні силові методи, які раніше застосовувалися для вирішення міжнародних конфліктів, більше не є ефективними.

Серед найрозвиненіших країн групи «нові індустріальні країни» Китай розглядають як одну із перспективних країн у світі, що посідає провідне місце як у сфері культури й освіти, так і на світовому ринку. Досягнення китайської економіки були б немождиві без правильно організованої освітньої системи у державі. Розвиток економіки потребує висококваліфікованих фахівців. Тому китайський уряд докладає величезних зусиль для розвитку освіти, інвестуе в освіту величезні кошти. Сьогодні рівень системи освіти в Китаї відповідає найвищим світовим стандартам. До освіти китайці ставдяться дуже серйозно. За останні п'ятнадцять років Китай витратив 3-4\% від загальної суми внутрішнього продукту на національну освіту, зробивши обов'язкову дев'ятирічну освіту

*C) Доценко С. O.

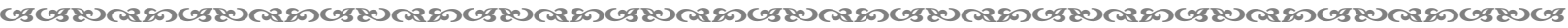


безкоштовною. Китайська система освіти - це державна система, що регуяюється Міністерством освіти.

Раптовий спалах COVID-19 на початку 2020 поставив на паузу швидкий і стійкий прогрес Китаю в соціально-економічному розвитку. Вірус також сильно вплинув на сферу освіти. На початку лютого 2020 року Міністерство освіти спільно 3 Міністерством промисловості та інформаційних технологій Китаю оголосили про закриття шкіл, але не про зупинку навчання.

У таких унікальних умовах упровадження масштабного он-лайн навчання для сотень мільйонів студентів по всій країні було безпрецедентним завданням. Ми стали свідками одного 3 найбільших у світі проєктів - модернізації інформаційної інфраструктури Китаю, що містить підготовку учнів, вчитедів, батьків, студентів та викладачів до дистанційного навчання. Цей проєкт став одним 3 найбільших випробувань онлайн освіти в усьому світі. Тому вивчення досвіду впровадження дистанційної освіти в Китаї $є$ необхідним та актуальним.

Аналіз досліджень. Теоретичну основу дослідження становлять положення порівняльної педагогіки (Н. Бідюк [1], А. Сбруєва [9], Д. Штефан [14] та ін.), питання економічного розвитку в КНР (Сунь Цзінцю [10], М. Титаренко [4] та ін.), історичні аспекти розвитку освіти в КНР (Є. Гобова [2], В. Кіктенко [4] та інші), професійна підготовка в КНР (Ван Цзін [3], О. Жерновникова [3], К. Шевченко [13] та ін.), дистанційна освіта в КНР (Н. Мирончук [5], В. Мумладзе [5], О. Шацька [12] та ін.).

Проблему дистанційного навчання почали вивчати ще від 1970 року. У різних країнах були зроблені спроби обгрунтувати феномен «навчання на відстані». Враховуючи значний внесок зарубіжних учених О. Петерса (O. Peters) [19], М. Мyра (M. Moore) [18], Б. Холмберга (B. Holmberg) [16], Д. Кигана (D. Keegan) [17], Р. Гаррісона (R. Garrison) [15] та ін., більшість наукових робіт, як і раніше, мають дескриптивний характер, що породжує необхідність подадьшого розвитку фундаментадьних основ дистанційної освіти.

Наявні дослідження 3 цієї проблеми - це калейдоскоп різних підходів, які окреслюють окремі аспекти дистанційної освіти. До найбільш загальних елементів, у тому чи іншому вигляді окреслених у більшості концепцій, відносять: 1) наявність географічної дистанції між учнем та вчителем (студентом або викладачем) у процесі навчання; 2) присутність нового типу освітньої комунікації, обумовленого поділом процесів викладання і навчання в часі та просторі; 3) вивчення дистанційної освіти як нової технологічної форми навчання, що виникла в інформаційному суспільстві. Отже, визначено три підходи до феномена «дистанційне навчання»: теорія індустріалізації, концепт відстані та характер освітньої комунікації.

Німецький дослідник О. Петерс був одним 3 перших, хто визначив дистанційне навчання як результат упливу процесу індустріалізації на різні сфери суспільства [19]. Відповідно до його концепції, таке навчання має ряд характеристик, які є схожими 3 процесом виробництва товарів в умовах індустріального суспільства, а саме: поділ праці (здійснюються розробка навчальних матеріалів), стандартизація та масове виробництво (виготовлення великої кількості стандартизованих освітніх матеріалів для будь-якої категорії тих, що навчаються), технологічність (наприклад, широке застосування телеі аудіо технологій у процесі навчання).

На відміну від технократичного підходу попередника, М. Мур і Б. Холмберг розглядали наявність відстані при дистанційному навчанні не стільки як географічну віддаленість вчителя та учня, скільки як ступінь взаємодії між ними [16; 18]. М. Мур зазначав, що наявність відстані між суб'єктами освітнього процесу є позитивним фактором, який сприяе розвитку самостійності того, кого навчають, його автономності, необхідної для реалізації поставлених цілей. Дистанція, змінюючи структуру навчання, вимагає від його учасників особливих особистісних якостей i навичок роботи, що дозволяють їм діяти незалежно один від одного [18, с. 661].

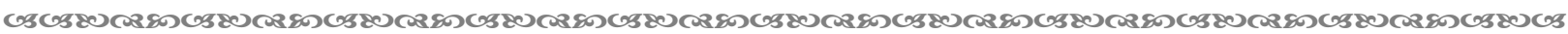
27 
Вивчаючи педагогічний потенціал дистанційної форми навчання, американський дослідник Д. Киган звертав увагу на те, що роз'єднаність у просторі передбачає поділ процесів навчання і викладання [17, с. 130]. Тим самим руйнується один із центральних принципів, на якому завжди будувалося освіта, - тісний контакт учня і вчителя, а отже, знижується результативність навчання.

у сучасних дослідженнях дистанційне навчання - це навчальний процес, який не залежить від наявності або відсутності географічної віддаленості його суб'єктів. На думку науковців [15-18] відмінною рисою дистанційного навчання є десинхронізація навчання, необов'язковість симультанності викладання та навчання.

Аналізуючи розвиток дистанційного навчання, зазначимо, що ця форма для держав є недорогою та обходиться на 50 \% дешевше за традиційну форму навчання. А витрати на підготовку вчителів до викладання в дистанційному форматі складають приблизно 60 \% від витрат на підготовку вчителів за традиційною формою навчання. Тому вже в 1997 році налічувалося тисяча навчальних закладів (107 країн світу), які використовують дистанційну форму навчання.

Китай був однією з перших країн, які почади широко використовувати дистанційне навчання через радіо і телебачення. На початку 1960-х рр. у Пекіні та в інших великих містах були створені перші регіональні телевізійні університети (RTVU), які повинні були допомогти дорослим здобути освіту. Так, у 1960-1966 рр. понад 8000 студентів стади випускниками Пекінського Телевізійного Університету. 1986 р. став поворотним моментом у розвитку системи телевізійних університетів у Китаї. Відбулися суттєві зміни у трьох напрямках: складання вступних іспитів, визначення цільової аудиторії та створення системи подання навчального матеріалу.

Відповідно до зазначених змін із 1986 року абітурієнти телевізійних університетів здають єдиний національний вступний іспит, що проводиться Державною комісією 3 питань освіти для прийому до всіх вищих навчальних закладів для дорослих. Отже, саме у 1986 р. RTVU почали прийом абітурієнтів, які щойно закінчили середню школу. Того ж року почалася щовечірня трансляція навчальних програм RTVU по каналах супутникового телебачення. Таким чином, до щотижневих тридцяти трьох годин навчальних програм університету CCTV (Центрального телебачення КНР), що передаються по мережі, додадися ще сорок дев'ять годин трансляції навчальних програм. Зазначені зміни створиди нові мождивості для поширення і подадьшого розвитку методики RTVU. Це вимагало створення єдиного органу, який контродює національну систему дистанційної освіти, визначає єдині вступні стандарти, навчальні плани, академічні рівні та критерії складання іспитів, вимоги до розробки програм тощо.

Стрімкий розвиток системи дистанційної освіти в Китаї стимулюється інтенсивним фінансуванням. Необхідні кошти на навчання студентів надходять із декількох джерел. Університет CRTVU керуе та фінансуе Державна комісія 3 питань освіти, а мовні канали CCTV і CETV несуть витрати за телевізійну трансляцію. Значна частина цих коштів спрямована на впровадження Інтернет-технологій в систему дистанційної освіти. Китай має найвищий річний темп використання електронного навчання (e-learning). Також майже всі китайські фірми використовували e-learning.

Сьогодні в КНР дистанційні курси є електронним аналогом занять у звичайній аудиторії університету. Для цього долучені найкращі викладачі провідних університетів Китаю, які пройшли багаторівневий національний конкурс. Для виходу дистанційної системи освіти на більш високий світовий рівень викладання Міністерство освіти КНР працює над переробкою та доповненням підручників для всіх рівнів освіти, особливо вищої структури, що вирішує стратегічне завдання розвитку країни. Запрошуються до китайських вишів провідні викладачі кращих університетів світу, які мають значний досвід роботи; використовуються інноваційні освітні технології; враховуються як націонадьні традиції, так і входження Китаю до світової спільноти. 
Таким чином, можна зробити висновок, що Китай є одним із дідерів щодо впровадження та розвитку дистанційної освіти відповідно світовим стандартам як в організаційному, так і в навчально-методичному плані, поєднуючи багатовікову національну традицію соціального інституту освіти, інновації та досягнення нашої планети в умовах глобалізації та інтеграції світового простору. Отже, вивчення досвіду впровадження дистанційної освіти в Китаї є вкрай актуальним та своєчасним.

Мета статті - вивчення та узагальнення досвіду впровадження дистанційної освіти в Китаї та його використання в національній системі освіти.

Виклад основного матеріалу. Китай має одну з найбільш розвинених систем дистанційного навчання у світі. Величезна територія та велика чисельність населення КНР стали природними передумовами для розвитку саме дистанційного навчання.

Масові відкриті онлайн-курси (МООС) в останні часи у Китаї стали однією 3 популярних технологій дистанційного навчання, що підвищило його ефективність та розширило можливості. Абревіатура МООС складається з чотирьох окремих термінів.

Massive (масовий): дана форма онлайн-навчання передбачає велику кількість студентів, яка не обмежена географічним положенням.

Open (відкритий): онлайн-навчання безкоштовне для всіх.

Online (онлайн): курси проводяться із використанням засобів онлайн зв'язку. Всі матеріали є у вільному доступі в електронному вигдяді.

Course (курс): структурована та впорядкована подача інформації, відповідно визначеним цілям, правилам роботи та тимчасовим обмеженням для кожного окремого учасника.

Отже, MOOC - це електронні курси (навчально-методичні комплекси), зміст яких представлено відеолекціями зі субтитрами, текстовими конспектами лекцій, домашніми завданнями, тестами та підсумковими іспитами. Однією 3 важдивих характеристик МООС є створення для кожного учня персонального освітнього середовища.

Масові відкриті онлайн-курси привертають велику увагу китайської освітньої спільноти. 2019 року в Пекіні проведена китайська конференція, у ході якої були підсумовані результати використання МООС. Так, на платформах представлено 500 спеціалізацій МООС, їх вивчають понад 200 мільйонів учнів різних навчальних закладів та 65 мільйонів із них отримали диплом МООС.

Китай став передовою країною в розробці та використанні курсів МООС. За даними Міністерства освіти КНР, зараз у країні налічуеться близько 3200 онлайн-курсів.

MOOC мають певні переваги. Першою перевагою є те, що вони «відкриті», тобто є доступними для учнів, які живуть як у великих містах, так і у невеликих селищах, провінціях. Розширення мережі Інтернет стирає бар'єри часу та простору, що робить освіту доступною для учнів незалежно від наповненості класів або фінансових мождивостей студентів. Іноді МООС порівнюються за значущістю 3 першими друкованими підручниками, які сприяли значному поширенню знань та заклали основи д,я розвитку науки і техніки.

Наступною важдивою перевагою МООС є їх «масовість». Джерелом онлайн-курсів на веб-сайтах MOOC є не одна, не дві людини або окремий освітній заклад, а бездіч людей та організацій, які готові безкорисливо ділитися своїми знаннями та навчальними програмами. Серед таких найбільші університети всього світу. Багатство та масштаб ресурсів МООС зробили великий внесок в освіту багатьох країн, що, у свою чергу, сприяло популярності самих МООС.

Ще однією важдивою характеристикою МООС є їх адаптивність. Ресурси на вебсайтах МООС представляють систему навчадьних програм, які вибудовують учням упорядкований та структурований маршрут навчання. МООС має певні вимоги до запису ресурсів, які стосуються їх тривалості та ефективності, тому учень отримуе знання систематично та послідовно. Йому пропонуються короткі відеородики, які 
супроводжується коментарями. Після їх перегляду надаються відповідні тестові питання для оцінки вивченого матеріалу.

Але розвиток МООС у Китаї має певні труднощі та проблеми. Перш за все, це проблема відсутності особистісної взаємодії між викладачами та студентами. Оскільки зв'язок між ними здійснюється через мережеву платформу, це позбавляє викладачів можливості безпосередньо спостерігати за прогресом студентів. Така ситуація може спровокувати студентів на фальсифікацію навчальних результатів. Таким чином, викладач не може гарантувати, що весь навчальний курс опанований самим учнем. Щоб запобігти виникненню цих явищ, навчання на курсах MOОС має створити відповідну систему контролю.

Ще однією проблемою впровадження МООС є обмеженість обсягу та різноманітності навчальних ресурсів. Наприклад, коли почалося масове поширення відкритих онлайн-курсів, більшість людей виявило зацікавленість та вирішило використовувати МООС для вивчення іноземних мов, зокрема англійської. Але таке вивчення ангдійської мови є дише суттєвим доповненням до вишівських курсів та підручників. Наприклад, якщо на будь-якому онлайн-курсі є іноземні студенти, рівень володіння англійською мовою може бути підвищений шляхом регулярної комунікації 3 ними. Вивчення англійської у сучасному Китаї багато в чому залишається консервативним та зосереджується в основному на аудіюванні, читанні, письмі та комплексній англійській мові, що не може задовольнити потреби всіх учнів.

Але зі збільшенням попиту на ангдійську мову в Китаї всі необхідні стандарти та чинні навчальні програми з англійської мови не були скориговані відповідно до вимог сучасних підприємств і організацій. Це призвело до того, що ніде не приділяеться належної уваги практичній стороні навчання, тому при подальшому працевлаштуванні випускники як вишів, так і курсів МООС не змогди задоводьнити вимоги організацій і підприемств.

Головною проблемою МООС є справедливість системи оцінювання. У традиційній системі оцінка знання англійської мови студентами, як правило, складається 3 певного відсотка поточних та підсумкових оцінок, тоді як при вивченні МООС важдивим є тільки проходження тестів. За таких умов деякі учні ігнорують послідовне структуроване вивчення англійської та намагаються прискорено вивчити матеріал безпосередньо перед тестом. Цей метод навчання не дозволяє засвоїти знання досить гдибоко, що сприяє забуванню матеріалу відразу після тесту. Тому необхідно прийняти нову систему оцінювання в межах МООС для об'єктивного визначення рівня засвоєння знань.

Деякі великі університети в Китаї вже почали вивчати моделі співпраці з установами, які мають великий досвід роботи з МООС. Наприклад, Пекінський університет та Університет Цінхуа стали першими в Азії університетами, що приєдналися до онлайн-платформи, створеної МІТ і Гарвардським університетом. Метою такого співробітництва є вивчення досвіду західних навчальних закладів для подальшого самовдосконалення та адаптування на їх основі відкритих онлайн-курсів відповідно китайським традиціям.

За підтримки Міністерства освіти Китаю та Національної комісії Китаю у справах ЮНЕСКО було запущено дві освітні онлайн-платформи: «XuetangX» (www.xuetangx.com) та «іCourse» (www.icourse163.com). Зазначені платформи надають якісні навчальні ресурси англійською та іншими мовами від провідних університетів світу та надійну технічну підтримку [6; 8].

Платформа «XuetangX» пропонуе понад 3000 онлайн-курсів від провідних університетів світу (Массачусетський технологічний інститут (МІТ), Каліфорнійский університет в Берклі (The University of California, Berkeley), Університет Цінхуа (Tsinghua University) та Пекинський університет (Peking University) та інших. Міжнародна версія XuetangX доступна 3 англомовним інтерфейсом. На платформу «Xuetang X» можна зайти із ноутбука, телефону або з інших цифрових пристроїв. Завдяки останнім розробкам

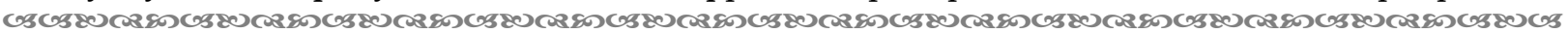


в області MOOK, XuetangX пропонуе онлайн-курси, лекції в прямому ефірі, сертифіковані програми, які відповідають освітнім потребам учнів у всьому світі.

Пиатформа «іCourse» була офіційно запущена Видавництвом вищої освіти Китаю у 2020 році [6]. Платформа надає можливість онлайн-викладання та навчання для іноземних викладачів та студентів по всьому світу. Основною мовою платформи є ангдійська. Платформа «іCourse» заснована 3 урахуванням накопиченого досвіду управління курсами та технічної підтримки iCourse China University, який об'єднує провідні університети Китаю (Пекінський університет, університет Фудань, університет Чжецзян).

Онлайн-курси ретельно продумані та відібрані. Їх викладають висококваліфіковані викладачі, а інтерактивна взаємодія здійснюється спеціально підготовденими співробітниками. На платформі розміщено курси за темами: медицина, природничі науки, інженерна справа та технології, сільське господарство та екологія, економіка та розвиток, мистецтво й дизайн, експерименти 3 інтелектуальним та віртуадьним моделюванням тощо. Також платформа може надавати необхідні функції для користувачів із різними родями: гість, викладач, асистент, студент, учень та інші. В основному це чотири системи: система онлайн-навчання, система управління курсом, система сертифікації навчання і система обслуговування даних.

Хоча Китай має достатню кількість освітніх онлайн-ресурсів, учителі в західних регіонах та сільській місцевості не звикли використовувати технології у сфері освіти або онлайн-ресурси. Спалах коронавірусу став приводом для створення випробувального майданчика для нових технологій, таких як штучний інтелект, 5G та хмарні сховища.

Департамент освіти провінції Гуандун запустив платформу дистанційного навчання, яка поєднує в собі високоякісні онлайн-курси від експериментальної середньої школи Гуандуна та дочірньої середньої шкоди Південно-Китайського педагогічного університету. Курси створено на платформі Talkweb та підтримуються хмарним сховищем HUAWEI Cloud. Платформа забезпечуе онлайн-викладання та навчання та надає освітні послуги для 25000 шкіл і 17 мільйонів вчителів та учнів усієї провінції [7].

Вчителі та учні використовують інтерактивну платформу навчального центру для взаємодії в режимі реального часу за допомогою текстових, аудіо та відео повідомдень, щоб ставити запитання та відповідати на них в онлайн-режимі. Це покращує участь учнів і дозволяє вчителям зрозуміти, як учні засвоюють інформацію. Заняття в прямому ефірі автоматично записуються і доступні для перегляду після занять.

Викладачі також можуть використовувати інтерактивну ручку для позначення основних моментів прямо під час уроку. Учень може віртуально підняти руку, щоб відповісти на питання або щоб взаємодіяти з викладачем в онлайн-режимі. Ці функції мають велике значення для відтворення сценаріїв навчання, до яких учні звикли під час традиційного навчання в школі. Платформа забезпечуе п'ять режимів навчання у класі в залежності від потреб. Після закінчення уроку в режимі реального часу система автоматично виконуе повний спектр аналізу даних за такими вимірами, як кількість онлайн-глядачів, кількість взаємодій та тривалість онлайн-занять.

Адміністратори та викладачі навчальних закладів можуть використовувати функцію віддаленого офісу на платформі HUAWEI CLOUD WeLink для проведення онлайн-зборів, онлайн-навчання та синхронізації інформації між учителем й учнем до початку занять. WeLink, що була створена Huawei, є повнофункціональною, безпечною, інтелектуальною та цифровою офісною платформою для спільної роботи. Це швидкий та ефективний спосіб для студентів відвідувати великомасштабні курси в режимі реального часу та взаємодіяти без необхідності зміни додатків або обдікового запису.

Висновки. На відміну від багатьох інших країн, у Китаї не вважають, що дистанційне навчання може повністю замінити університетський кампус. Дистанційне навчання розглядається як додаткова освіта, особливо після закінчення навчання у ВНЗ. Також стають актуальними проблеми розвитку МООС відповідно до

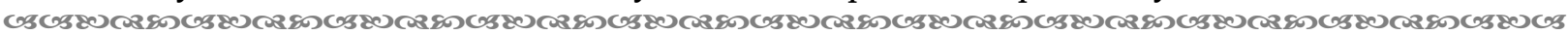


китайської культури, 3 урахуванням переваг та недоліків МООС; проблеми їх практичного застосування, що засновані на чесності студентів у процесі навчання на курсах MOОС. До першочергових завдань на шляху розв'язання цих проблем може бути віднесено: 1) грунтовне вивчення переваг та недоліків МООС; 2) розширення міжнародного співробітництва у сфері застосування МООС; 3) залучення більшого числа учнів для роботи в інформаційному середовищі MOOC; 4) здійснення процесів державної стандартизації та надання підтримки з боку уряду.

Таким чином, досвід Китаю може бути оперативно апробований та застосований для підвищення ефективності управління якістю педагогічних технологій, які застосовуються в українській системі дистанційного навчання. Однак, при цьому слід зазначити, що, незважаючи на безперечну цінність напрацьованого зарубіжними освітніми системами досвіду, в тому числі у галузі управління якістю педагогічних технологій, не все є прийнятним для впровадження в національній освіті. Перспективи подальших досліджень полягатимуть у створенні порівняльної характеристики організації процесу дистанційного навчання в Китаї та Україні.

\section{Список використаних джерел:}

1. Бідюк Н. Порівняльно-педагогічні дослідження у контексті розвитку інтеграційних процесів в освіті. Університет на шляху Болонських перетворень: зб. наук.-метод. пр. / за заг. ред. М. Скиби, С. Костогриза. Хмельницький : ХНУ, 2012. С. 73-76.

2. Гобова Є. Сорок років розвитку науки та освіти в Китаї. URL: https://sinologist.com.ua/gobovaye-v-sorok-rokiv-rozvytku-nauky-ta-osvity-v-kytayi/

3. Жерновникова О., Ван Цзін І. Формування та становлення особистості майбутнього педагога засобами музичного мистецтва. Педагогічний альманах: збірник наукових праць / редкол. В. В. Кузьменко (голова) та ін. Херсон: КВНЗ «Херсонська академія неперервної освіти», 2017. Випуск 36. С. 208-212.

4. Кіктенко В. Історія українського китаєзнавства (XVIII - початок XXI століття). Київ, 2018. 388 с.

5. Мумладзе В., Мирончук Н. Вища педагогічна освіта в Китаї. Модернізація вищої освіти в Україні та за кордоном. Житомир: ЖДУ ім. І. Франка, 2014. С. 200-203.

6. Платформа iCourse. URL: http://www.icourse163.com

7. Пиатформа Talkweb. URL: https://web.talklife.com

8. Пиатформа XuetangX. URL: https://www.xuetangx.com/

9. Сбруєва. А. Порівняльна педагогіка: навч. посіб. Суми, 1999. 300 с.

10. Сунь Цзінцю. Основні чинники розвитку системи освіти в КНР у другій половині ХХ століття. URL: https://journals.indexcopernicus.com/api/file/viewByFileId/326593.pdf

11. Титаренко М. А. Китай: цивилизация и реформы. Москва: Республика, 1999. 240 с.

12. Шацька О. Іншомовна підготовка студентів засобами сучасних технологій у ВНЗ Камбоджі, Таїланду та КНР. Сучасні інформаційні технологї та інноваційні методики навчання в підготовці фахівиів: методологія, теорія, досвід, проблеми. 2014. Вип. 38. С. 483-487.

13. Шевченко К. Підготовка бакалаврів освіти у педагогічних університетах КНР: дис. ... канд. пед. наук: 13.00.04 / НАПН України. Київ, 2018. 343 с.

14. Штефан $\Lambda$. Особливості навчання студентів у провідних країнах світу. Педагогічні науки. 2015, B. 64, C. $45-51$.

15. Garrison R. Theoretical challenges for distance education in the 21st century: A shift from structural to transactional issues. International Review of Research in Open and Distance Learning. 2000. № 1 (1). P. 3-15.

16. Holmberg B. Guided didactic conversation in distance education, in D. Sewart \& B. Holmberg (eds.), Distance Education: International Perspectives. London: Croom Helm, 1983. P. 114-122.

17. Keegan D. Reintegration of the teaching acts. In Keegan, D. (Ed.). Theoretical principles of distance education. L.; N. Y.: Routledge. 1993. P. 113-134.

18. Moore M. Toward a theory of independent learning and teaching. Journal of Higher Education. 1973. № 44 (12). P. 661-679.

19. Peters O. Distance teaching and industrial production: a comparative interpretation in outline, in D. Sewart, D. Keegan y B. Holmberg (eds.), Distance Education: International Perspectives. London Croom Helm, 1983. 21 p. 


\section{References:}

1. Bidiuk, N. (2012). Porivnialno-pedahohichni doslidzhennia u konteksti rozvytku intehratsiinykh protsesiv $\mathrm{v}$ osviti [Comparative and pedagogical research in the context of the development of integration processes in education]. Universytet na shliakhu Bolonskykh peretvoren, 73-76 [in Ukrainian].

2. Hobova, Ye. (2018). Sorok rokiv rozvytku nauky ta osvity v Kytai [Forty years of development of science and education in China]. Retrieved from https://sinologist.com.ua/gobova-ye-v-sorokrokiv-rozvytku-nauky-ta-osvity-vytayi/[in Ukrainian].

3. Zhernovnykova, O. A., \& Wang, Jingyi (2017). Formuvannia ta stanovlennia osobystosti maibutnoho pedahoha zasobamy muzychnoho mystetstva [Formation and development of the future teacher's personality by means of musical art]. Pedahohichnyi almanakh, 36, 208-212 [in Ukrainian].

4. Kiktenko, V. (2018). Istoriia ukrainskoho kytaieznavstva (XVIII - pochatok XXI stolittia) [History of Ukrainian Chinese studies (XVIII - early XXI century)]. Kyiv [in Ukrainian].

5. Mumladze, V., \& Myronchuk, N. (2014). Vyshcha pedahohichna osvita v Kytai [Higher pedagogical education in China]. Modernizatsiia vyshchoi osvity v Ukraini ta za kordonom, 200-203 [in Ukrainian].

6. Platforma iCourse [Platform iCourse]. Retrieved from http://www.icourse163.com [in English].

7. Platforma Talkweb [Platform Talkweb]. Retrieved from https://web.talklife.com [in English].

8. Platforma XuetangX [Platform XuetangX]. Retrieved from https://www.xuetangx.com/ [in English].

9. Sbruieva, A. (1999). Porionialna pedahohika [Comparative pedagogy]. Sumy [in Ukrainian].

10. Sun, Tszintsiu. (2017). Osnovni chynnyky rozvytku systemy osvity v KNR $\mathrm{u}$ druhii polovyni XX stolittia [The main factors in the development of the education system in China in the second half of the twentieth century]. Retrieved from https://journals.indexcopernicus.com/api/file/viewByFileId/326593.pdf [in Ukrainian].

11. Titarenko, M. (1999). Kitai: tcivilizatciia i reformy [China: civilization and reform]. Moskva: Respublika [in Russian].

12. Shatska, O. (2014). Inshomovna pidhotovka studentiv zasobamy suchasnykh tekhnolohii u VNZ Kambodzhi, Tailandu ta KNR [Students' foreign language training by means of modern technologies in universities of Cambodia, Thailand and China]. Suchasni informatsiini tekhnolohii ta innovatsiini metodyky navchannia $v$ pidhotovtsi fakhivtsiv: metodolohiia, teoriia, dosvid, problemy, 38, 483-487 [in Ukrainian].

13. Shevchenko, K. (2018). Pidhotovka bakalavriv osvity u pedahohichnykh universytetakh KNR [Training of bachelors of education in pedagogical universities of the People's Republic of China]. (Candidate's thesis). Kyiv [in Ukrainian].

14. Shtafan, L. (2015). Osoblyvosti navchannia studentiv u providnykh krainakh svitu [Features of students' education in the leading countries of the world]. Pedahohichni nauky, 64, 45-51 [in Ukrainian].

15. Garrison, R. (2000). Theoretical challenges for distance education in the 21st century: A shift from structural to transactional issues. International Review of Research in Open and Distance Learning, 1 (1), 3-15 [in English].

16. Sewart, D. \& Holmberg, B. (Ed.). (1983). Guided didactic conversation in distance education. Distance Education: International Perspectives, 114-122 [in English].

17. Keegan, D. (Ed.). (1993). Reintegration of the teaching acts. Theoretical principles of distance education, 113-134 [in English].

18. Moore, M. (1973). Toward a theory of independent learning and teaching. Journal of Higher Education, 44 (12), 661-679 [in English].

19. Peters, O. (1983). Distance teaching and industrial production: a comparative interpretation in outline. Distance Education: International Perspectives, 21 [in English].

Dotsenko S. O., orcid.org/0000-0002-4501-9130

\section{EXPERIENCE OF DISTANCE LEARNING ARRANGEMENT IN CHINA}

The article deals with the experience of China, which is recognized as a leader in the field of distance learning implementation. The objectives of the study are to cover the history of distance education in China and to identify features and ways of its effective implementation. The methodological basis of the research is basic concepts of comparative pedagogy, issues of economic development in China, 
historical aspects of the Chinese education system development, problems of professional teacher development in China and the history of distance education in China. The aspects of distance education have been outlined: 1) a geographical distance between the student and the teacher in the learning process (at secondary schools and higher educational establishments); 2) a new type of learning communication, which is due to the separation of teaching and learning processes in time and space; 3) the study of distance education as a new technological form of education that emerged in the information society. Three approaches to the phenomenon of "distance education" have been identified: industrialization theory, concept of distance and the nature of educational communication. The following methods of research have been used: generalization and comparison methods which help to study the connections between different approaches; concept classification method; critical thinking method, prognostic research method.

The emphasis is put on the use of massive open online courses (MOOCs) which are in demand in China. The advantages of MOOCs have been mentioned: openness, massiveness and adaptability. The difficulties of the use of MOOCs have been defined: lack of personal interaction between teachers and students; limited scope and diversity of educational resources and the fairness of evaluation systems. The educational platforms, enabling to provide MOOCs: "XuetangX" and "iCourse" have been analyzed. The novelty of the study is to identify the efficient and true tried ways of arranging distance education in China which can be tested promptly in Ukrainian system of education.

Key words: digitalisation in education, COVID-19, distance education/learning, China, MOOC, online classes, XuetangX, iCourse International.

Дата надходження статті: 23.122020 p.

Рецензент: доктор педагогічних наук, професор Жерновникова О. А.

УДК 370/1^54(075.2)

DOI https://doi.org/10.37915/pa.vi47.146

Сидорович М. М.,

orcid.org/0000-0003-1302-3378

\section{ПІДВИЩЕННЯ ТЕОРЕТИЧНОГО РІВНЯ НАВЧАННЯ БІОЯОГІЇ У ЗАКДАДАХ ЗАГАЯЬНОЇ СЕРЕДНЬОЇ ОСВІТИ: СТАН РОЗРОБЛЕННЯ ПРОБЛЕМИ В ТЕОРІЇ}

У статті проаналізовано стан розроблення проблеми підвищення теоретичного рівня навчання біології в сучасній педагогічній теорії. 3'ясовано, щзо однією з провідних настанов навчання біологї в украӥнських закладах загальної середньої освіти є розв'язання вказаної проблеми. Провідним напрямком ї̈ вирішення є виокремлення науково-теоретичного базису іна його основі розроблення підходів щодо підвищення теоретичного рівня формування знань учнів про живу природу в сучасній українській школі. Першим етапом иього процесу стало аналітичне дослідження стану розроблення вказаної проблеми у зарубіжній $і$ вітчизняній педагогічній теорії. Відстежено тендениії вказаного у методиках навчання біології дальнього, ближнього зарубіжжя і Украӥни впродовж середини - кіния XX $i$ початку XXI століть. Виокремлено риси подібності та відмінності у розв'язанні проблеми підвищення теоретичного рівня біологічної освіти у зарубіжній і вітчизняній педагогічній теорії. Здійснене аналітичне дослідження дозволило з'ясувати, що проблема підвищення теоретичного рівня біологічної освіти у зарубіжній і вітчизняній педагогічній теорії все ще залишається нагальною; вона є більш актуальною для вітчизняної методики навчання біології, ніж для відповідної методики дальнього зарубіжжя; науковиі вбачають підвищення теоретичного рівня навчання біологї уиілеспрямованому формуванні теоретичних біологічних знанъ, розумінні провідних узагальнень науки про життя в учнів; розглянуто окремі аспекти процесу формування

*(C) Сидорович M. M.

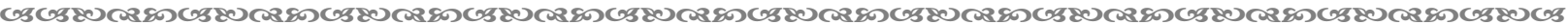

